Jurnal Diversita, 4 (2) Desember (2018) ISSN 2461-1263 (Print) ISSN 2580-6793 (Online)

DOI: http://dx.doi.org/10.31289/diversita.v4i2.1983

\title{
Jurnal Diversita
}

Available online http://ojs.uma.ac.id/index.php/diversita

\section{Pengaruh Budaya Organisasi, Tim Kerja dan Motivasi Intrinsik terhadap Komitmen Normatif Guru Sekolah Dasar Negeri di Batang \\ Kuis \\ The Effect of Organizational Culture, Work Team, and Intrinsic Motivation with Elementary Teacher's Normative Commitment in Batang Kuis}

Rapika Kesatriani Damanik*, M. Hilmi Irawan Tarigan, Selna Aprilia Sidauruk \& Septiana G.A.N

Fakultas Ekonomi, Universitas Negeri Medan, Indonesia

Diterima: Oktober 2018; Disetujui: November 2018; Dipublish: Desember 2018

*Corresponding author: E-mail: rapikadamanik01@gmail.com

\begin{abstract}
Abstrak
Tujuan penelitian ini adalah: (1) untuk mengetahui apakah ada pengaruh budaya organisasi sekolah terhadap motivasi intrinsik guru, (2) tim kerja guru terhadap motivasi intrinsik guru, (3) budaya organisasi sekolah terhadap komitmen normatif guru, (4) untuk mengetahui apakah ada pengaruh tim kerja guru terhadap komitmen normatif guru, (5) untuk mengetahui apakah ada pengaruh motivasi intrinsik guru terhadap komitmen normatif guru dan (6) untuk mengetahui apakah ada pengaruh budaya organisasi dan tim kerja guru terhadap komitmen normatif guru melalui motivasi intrinsik guru (pengaruh tidak langsung). Hasil Penelitian menunjukkan (1) Terdapat pengaruh langsung positif yang signifikan antara budaya organisasi dan tim kerja guru terhadap motivasi intrinsik baik secara sendirisendiri sebesar 0,399 dan 0,414. (2) Terdapat pengaruh langsung positif yang signifikan antara budaya organisasi, tim kerja guru dan motivasi intrinsik secara sendirisendiri terhadap komitmen normatif guru sebesar 0,324, 0181 dan 0,169. (3) Terdapat pengaruh tidak langsung antara budaya organisasi dan tim.
\end{abstract}

Kata kunci : Komitmen Normatif, Budaya Organisasi, Tim Kerja, dan Motivasi Intrinsik

\begin{abstract}
This study aimed to determine (1) the effect of organizational culture to intrinsic motivation, (2) the effect of work team to intrinsic motivation, (3) the effect of organizational culture to normative commitment, (4) the effect of work team to normative commitment (5) the effect of intrinsic motivation to normative commitment and (6) the undirect effect who organizational culture and work team to normative commitment weather intrinsic motivation. The result showed that: (1) There is a significant direct possitive of effect between organizational culture and work team, individually to intrinsic motivation with significance level of 0,399 and 0,414. (2) There is a significant direct possitive of effect between organizational culture, work team and intrinsic motivation, individually to normative commitment with significance level of 0,324,0,181 and 0,169. (3) There is a indirect effect between organizational culture and work team, individually to normative commitment with the significance level of 0,210 and 0,229 weather intrinsic motivation. The study concluded: (1) Organizational culture and work team has a direct effect, individually to intrinsic motivation by $16 \%$ and $17 \%$. (2) Organizational culture, work team and intrinsic motivation, individually has a direct effect to normative commitment by 10\%, 3,3\% and 2,8\%. Thus suggested to improve the normative commitment should be increased organizational culture, work team and intrinsic motivation of teacher.
\end{abstract}

Key words : Normative Commitment, Organizational Cultute, Work Team, and Intrinsic Motivation

How to Cite: Damanik, R.K., Tarigan, M.H.I., Sidauruk, S.A., \& N, S.G.A. (2018). Pengaruh Budaya Organisasi, Tim kerja, dan Motivasi Intrinsik terhadap Komitmen Normative Guru Sekolah Dasar Negeri di Batang Kuis. Jurnal Diversita, Vol 4 (2): 127-131. 


\section{PENDAHULUAN}

Guru sebagai pelaksana pendidikan memegang peranan penting dan strategis dalam penentuan tercapainya tujuan pembelajaran. Guru tidak hanya bertanggung jawab menyampaikan pelajaran, tetapi juga harus dapat menciptakan suasana belajar yang menyenangkan. Betapapun baik danlengkapnya sarana dan prasarana pendidikan, kurikulum, media, sumber atau hebatnya teknologi pendidikan, semua itu tidak akan berarti apa-apa jika tidak dibarengi dengan komitmen kerja yang baik. Dalam bekerja guru harus memiliki rasa tanggung jawab dan dedikasi yang tinggi terhadap pekerjaan itu sendiri maupun terhadap lingkungan pekerjaannya. Guru akan bekerja dengan penuh rasa tanggung jawab dan dedikasi yang tinggi jika memiliki komitmen organisasi. Komitmen adalah tekad yang bulat untuk mencapai suatu tujuan yang telah disepakati.

Menurut Homby (dalam Purba, 2010) komitmen adalah kerelaan untuk bekerja keras dan memberikan energi serta waktu untuk sebuah pekerjaan atau aktivitas. Selanjutnya Lincoln (dalam Sopiah, 2008) mengemukakan bahwa komitmen organisasi mencakup kebanggaan anggota, kesetiaan anggota dan kemauan anggota dalam organisasi. Keberhasilan seseorang dalam suatu tugas yang diberikan kepadanya dapat ditentukan oleh bagaimana komitmen mereka pada tugas dan tingkat pendidikan atau pengetahuannya. Menurut Luthans (2006) komitmen organisasi terdiri dari tiga komponen yaitu komponen afektif (affective commitment), komitmen kontiniu (continuance commitment), dan komitmen normatif (normative commitment). Komitmen afektif adalah komitmen organisasi yang lebih menekankan pada pentingnya kongruensi (kesebangunan) antara nilai dan tujuan karyawan dengan nilai dan tujuan organisasi. Komitmen kontiniu adalah komitmen organisasi dimana pekerja akan bertahan atau meninggalkan organisasi karena melihat adanya pertimbangan rasional dari segi untung dan ruginya. Komitmen normatif adalah komitmen organisasi dimana pekerja bertahan dalam organisasi karena ia merasakan adanya kewajiban.

$$
\text { Selanjutnya Luthans }
$$
mengatakan bahwa seseorang dengan komitmen normatif tidak harus merasa terikat secara emosional (komitmen afektif) ataupun tidak dikarenakan materi atau pemenuhan kebutuhan (komitmen kontiniu). Seseorang yang memiliki komitmen normatif tinggi dikarenakan adanya perasaan wajib untuk tetap berada dalam organisasi karena memang harus begitu, tindakan tersebut adalah hal benar yang harus dilakukan. Komitmen normatif guru berperan penting dalam meningkatkan kualitas pendidikan karena rasa tanggung jawab guru atas pekerjaannya. Kelemahan guru dalam memahami profesinya akan melemahkan fungsi guru secara perlahan sehingga mengakibatkan hubungan antara siswa dan guru tidak lagi saling membutuhkan. Pada gilirannya, situasi pembelajaran menjadi tidak lagi menyenangkan dan dapat menimbulkan konflik antara berbagai pihak di dalamnya sehingga berakibat pada proses pembelajaran yang menjadi terganggu. 
Jika komitmen normatif guru dibangun dengan baik maka guru akan berada di sekolah pada saat jam pelajaran, guru bertanggung jawab terhadap tugasnya, meningkatnya motivasi guru dalam peningkatan kualitas dirinya, minimnya konflik antar guru maupun kepala sekolah, guru tidak meninggalkan kelas saat jam pelajaran, tidak ada lagi jarak diantara guru dan kepala sekolah, minimnya penilaian yang bersifat subjektif serta tidak akan ada lagi guru yang datang terlambat datang ke sekolah.

Colquiit, LePine, dan Wesson (2009) menggambarkan bahwa komitmen dipengaruhi oleh faktorfaktor baik faktor langsung maupun tidak langsung. Faktor yang secara tidak langsung mempengaruhi komitmen meliputi: budaya organisasi (organizational culture), struktur organisasi (organizational structure), gaya dan perilaku kepemimpinan (leadership style and behavior), kekuatan dan pengaruh kepemimpinan (leadership power and influence), proses dan karakteristik tim (processes and characterisrics team), personal dan nilai budaya (personaity and cultural values), dan kemampuan (ability). Sedangkan faktor yang secara langsung mempengaruhi komitmen meliputi: kepuasan kerja (job satisfaction), stres (stress), motivasi (motivation), kepercayaan, keadilan, dan etika (trust, justice, and ethics), dan pengambilan keputusan (learning and decision making).

Faktor dalam penelitian ini yang diduga kuat mempengaruhi komitmen normatif guru adalah budaya organisasi di sekolah, tim kerja guru dan motivasi intrinsik guru. Yulk (2007) mengungkapkan perubahan skala besar dalam sebuah organisasi biasanya membutuhkan suatu perubahan dalam budaya organisasi. Dengan mengubah budaya sebuah organisasi, manajemen puncak secara langsung dapat mempengaruhi motivasi dan prilaku para anggota organisasi. Dengan adanya budaya yang baik, motivasi intrinsik akan terbentuk dan mengakibatkan peningkatan pada komitmen khususnya komitmen normatif para guru.

Selain itu, Luthans (dalam Sutrisno, 2009) juga mengungkapkan bahwa komitmen ditentukan oleh variabel personal dan variabel organisasi. Variabel personal meliputi usia dan masa jabatan dalam organisasi, sedangkan variabel organisasi meliputi rancangan tugas, gaya kepemimpinan, serta budaya dan iklim dalam organisasi organisasi itu. Berdasarkan hal tersebut dapat diartikan bahwa budaya yang baik dalam suatu organisasi akan memicu timbulnya motivasi guru sehingga dapat meningkatkan komitmen normatif para guru. Tim kerja juga merupakan salah satu yang mempengaruhi komitmen. Greenberg dan Baron (2003) berpendapat bahwa tim kerja adalah tim yang beranggotakan orang-orang yang fokus terutama dengan menggunakan sumber daya organisasi untuk secara efektif menciptakan hasil-hasilnya.

\section{METODE PENELITIAN}

Penelitian ini dilaksanakan pada guru-guru SD Negeri di Kecamatan Batang Kuis Kabupaten Deli Serdang Provinsi Sumatera Utara pada bulan November s/d Desember 2016. Penelitian ini dilakukan dengan menggunakan metode kuantitatif. Model yang digunakan adalah model 
analisis jalur (path analysis). Populasi target pada penelitian ini adalah seluruh guru-guru SDN di Kecamatan Batang Kuis yang berjumlah 319 orang. Pengambilan jumlah sampel pada penelitian ini dilakukan dengan menggunakan Tabel Nomogram Harry King dengan tingkat kesalahan sebesar 5\% maka diperoleh jumlah sampel sebesar 153 orang. Selanjutnya pengambilan sampel untuk setiap sekolah dilaksanakan secara random sampling.

\section{HASIL DAN PEMBAHASAN}

Terdapat pengaruh langsung positif antara Budaya Organisasi Sekolah (X1) terhadap Motivasi Intrinsik Guru (X3) dimana besarnya pengaruh yaitu $16 \%$ dan koefisien jalur antara X1 dengan X3 ( $\rho 31)=0,399$ dengan besar thitung $=5,33$. Hasil ini dikonsultasikan dengan ttabel pada $\mathrm{N}=153$ pada $\alpha=0,05$ sebesar 1,96 . Dengan demikian hipotesis yang diajukan bahwa terdapat pengaruh positif dan berarti antara budaya organisasi sekolah terhadap motivasi intrinsik guru dapat diterima dan teruji kebenarannya.

Terdapat pengaruh langsung positif antara Tim Kerja Guru (X2) terhadap Motivasi Intrinsik Guru (X3) dimana besarnya pengaruh yaitu $17 \%$ dan koefisien jalur antara X2 dengan X3 $(\rho 32)=0,414$ dengan besar thitung $=5,58$. Hasil ini dikonsultasikan dengan ttabel pada $\mathrm{N}=153$ pada $\alpha=0,05$ sebesar 1,96 . Dengan demikian hipotesis yang diajukan bahwa terdapat pengaruh positif dan berarti antara tim kerja guru terhadap motivasi intrinsik guru dapat diterima dan teruji kebenarannya.

Terdapat pengaruh langsung positif antara Budaya Organisasi Sekolah (X1) terhadap Komitmen Normatif Guru (X4) dimana besarnya pengaruh yaitu $10 \%$ dan koefisien jalur antara X1 dengan X4 $(\rho 41)=0,324$ dengan besar thitung $=4,19$. Hasil ini dikonsultasikan dengan ttabel pada $\mathrm{N}=153$ pada $\alpha=0,05$ sebesar 1,96. Dengan demikian hipotesis yang diajukan bahwa terdapat pengaruh positif dan berarti antara budaya organisasi sekolah terhadap komitmen normatif guru dapat diterima dan teruji kebenarannya

Terdapat pengaruh langsung positif antara Tim Kerja Guru (X2) terhadap Komitmen Normatif Guru (X4) dimana besarnya pengaruh yaitu $3,3 \%$ dan koefisien jalur antara X2 dengan X4 ( $\rho 42)=0,181$ dengan besar thitung $=2,26$. Hasil ini dikonsultasikan dengan ttabel pada $\mathrm{N}=153$ pada $\alpha=0,05$ sebesar 1,96. Dengan demikian hipotesis yang diajukan bahwa terdapat pengaruh positif dan berarti antara tim kerja guru terhadap komitmen normatif guru dapat diterima dan teruji kebenarannya.

Terdapat pengaruh langsung positif antara Motivasi Intrinsik Guru (X3) terhadap Komitmen Normatif Guru (X4) dimana besarnya pengaruh yaitu 2,8\% dan koefisien jalur antara X3 dengan X4 ( $\rho 42)=0,169$ dengan besar thitung $=2,10$. Hasil ini dikonsultasikan dengan ttabel pada $\mathrm{N}=153$ pada $\alpha=0,05$ sebesar 1,96 . Dengan demikian hipotesis yang diajukan bahwa terdapat pengaruh positif dan berarti antara motivasi intrinsik guru terhadap komitmen normatif guru dapat diterima dan teruji.

\section{SIMPULAN}

Berdasarkan data dan hasil analisis yang telah dipaparkan di atas, maka dapat diambil beberapa kesimpulan yakni 
terdapat pengaruh langsung positif antara budaya organisasi sekolah terhadap motivasi intrinsik guru. Hal ini menandakan semakin tinggi atau baiknya budaya organisasi sekolah akan mengakibatkan semakin tinggi pula motivasi intrinsik para guru yang ada di SD Negeri Kecamatan Batang Kuis.

Selain itu, terdapat pengaruh langsung positif antara tim kerja guru terhadap motivasi intrinsik guru. Hal ini menandakan semakin tinggi atau baiknya tim kerja guru dalam sekolah akan mengakibatkan semakin tinggi pula motivasi intrinsik para guru yang ada di SD Negeri Kecamatan Batang Kuis.

Terdapat pengaruh langsung positif antara budaya organisasi terhadap komitmen normatif guru. Hal ini menandakan semakin tinggi atau baiknya budaya organisasi sekolah akan mengakibatkan semakin tinggi pula komitmen normatif para guru yang ada di SD Negeri Kecamatan Batang Kuis.

Terdapat pengaruh langsung positif antara tim kerja guru terhadap komitmen normatif guru. Hal ini menandakan semakin baik tim kerja guru yang dibangunkan mengakibatkan semakin tinggi komitmen normatif para guru yang ada di SD Negeri Kecamatan Batang Kuis.

Terdapat pengaruh positif langsung antara motivasi intrinsik guru terhadap komitmen normatif guru. Hal ini menandakan semakin tinggi atau baiknya motivasi intrinsik para guru akan mengakibatkan semakin tinggi pula komitmen normatif para guru yang ada di SD Negeri Kecamatan Batang Kuis.

\section{DAFTAR PUSTAKA}

Arikunto, S. (2010). Prosedur Penelitian, suatu Pendekatan Praktik. Jakarta: Rineka Cipta

Colquitt,J. A., Jeffry A., Lepine, M J., Wesson. (2009). Organizational Behavior: Improving Performance and Commitment In The Work Place. New York: McGraw-Hill Companies

Ivancevich, J. M. Robert, K., \& Michael T.M (2006). Perilaku Manajemen Organisasi. Alih Bahasa: Gina Gania. Jakarta: Erlangga.

Luthans, F. (2006). Perilaku Organisasi.Yogjakarta: Andi Offset

Purba, S. (2010). Kinerja Pimpinan Jurusan di Perguruan Tinggi. Yogyakarta: LaksBang Pressindo

Robbins, S.P.,\& Judge, T. I (2009). Perilaku Organisasi (Organizational Behavior). Jakarta: Salemba Empat

Simanjuntak, E.T.H. (2012). Pengaruh Budaya Organisasi, Kepemimpinan dan Kepuasan Kerja Terhadap Komitmen Organisasi Guru SMK Sub Rayon 3 Pematang Siantar". Tesis. Pascasarjana Administrasi Pendidikan, Unimed: Medan.

Sopiah. (2008). Perilaku Organisasi.

Edisi Pertama. Yogyakarta: Andi Offset

Spector, P.E. (200o). Industrial and Organizational Psychology, Second Edition. New Jersey: John and Sons Inc.

Sudjana.(1996). Metode Statistika. Bandung: Tarsito

Sugiono. (2012). Metode Penelitian Pendidikan, Pendekatan Kuantitatif, Pendekatan Kualitatif,dan RED. Bandung: Alfabeta

Sutrisno, E. (2009). Manajemen Sumber Daya Manusia. Kencana: Jakarta

Umam, K. (2010). Perilaku Organisasi. Bandung: Pustaka Setia 